\title{
HOUSE FLY (MUSCA DOMESTICA) AS A TRANSPORT VECTOR OF GIARDIA LAMBLIA
}

\author{
Olga Doiz, Antonio Clavel, Santiago Morales, Marzo Varea, F. Javier Castillo, Carmen Rubio and Rafael \\ Gómez-Lus
}

Departamento de Microbiología, Facultad de Medicina, Universidad de Zaragoza, c/ Domingo Miral s/n, 50009 Zaragoza, Spain

The role of arthropods in the indirect transmission of giardiasis has been long suspected but little investigated. A polymerase chain reaction (PCR) assay specific for a heatshock protein (HSP) gene of Giardia lamblia (Lambl, 1859) was used for the direct detection of $G$. lamblia DNA in house flies (Musca domestica L.) captured in two towns in Aragón (Spain). Six hundred flies were captured and clustered in groups of ten, and each group was processed separately. An amplification product of the expected size (163 bp) was detected in 13 of the 60 groups (22\%).

Giardia lamblia (Lambl, 1859) is an enteric parasitic protozoon from humans and animals, and is a common cause of parasitic infections in humans in Spain and other countries (Jarabo M.T., García-Morán N.P., García-Morán J.L. 1995: Enferm. Infecc. Microbiol. Clin. 13: 464-468; RodríguezHernández J., Canut-Blasco A., Martín-Sanchez A.M. 1996: Eur. J. Epidemiol. 12: 291-295; Del Aguila C., Navajas R., Gurbindo D., Ramos J.T., Mellado M.J., Fenoy S., Muñoz Fernández M.A., Subirats M., Ruiz J., Pieniazek N.J. 1997: J. Euk. Microbiol. 44: 84S-85S). Numerous waterborne outbreaks of giardiasis have been documented (Kirner J.C., Littler J.D., Angelo L.A. 1978: J. Am. Water Works Assoc. 70: 3540; Dykes A.C., Juranek D.D., Lorenz R.A., Sinclair S.P., Jakubowski W., Davies R.B. 1980: Ann. Intern. Med. 92: 165170; Hibler C.P. 1988: In: P.M. Wallis and B.R. Hammond (Eds.), Advances in Giardia Research, University of Calgary Press, Calgary, pp. 197-204; Kent G.P., Greenspan J.R., Herndon J.L., Mofenson L.M., Harris J.A., Eng T.R., Waskin H.A. 1988: Am. J. Public Health 78: 139-143), but the role of other indirect transmission mechanisms (for example arthropods) has not been extensively studied. Giardia cysts have been found in flies (Khan A.R., Huq F. 1978: Bangladesh Med. Res. Counc. Bull. 4: 86-93; Sterling C.R., Miranda E., Gilman R.H. 1987: Am. J. Trop. Med. Hyg. 36, Suppl.: 233) and cockroaches (Kasprzak W., Majewska A. 1981: Wiad. Parazytol. 27: 555-563). Given the low infective dose of Giardia cysts (Rendtorff R.C. 1954: Am. J. Hyg. 59: 209-220), arthropods, and especially flies, could be an important vehicle between faeces and food; promiscuouslanding synanthropic flies are recognised as transport hosts for a variety of protozoan and metazoan parasites in addition to viral and bacterial pathogens of public health importance (Graczyk T.K., Cranfield M.R., Fayer R., Bixler H. 1999: Am. J. Trop. Med. Hyg. 61: 500-504). It was the purpose of this work to detect possible Giardia lamblia cysts naturally occurring in house flies in our geographical area.

In July and August, 1998, twenty adhesive fly traps were set outdoors in two towns in Aragón (north-eastern Spain) where cattle and sheep are raised. House flies (Musca domestica L.) captured in them were selected and crushed in a mortar in groups of ten; each group was resuspended separately in $4.5 \mathrm{ml}$ of PBS. Approximately $200 \mu \mathrm{l}$ of the suspension, $900 \mu \mathrm{l}$ of L6 lysis buffer $(10 \mathrm{M}$ guanidinium thiocyanate, $0.1 \mathrm{M}$ Tris-hydrocholoride $\mathrm{pH} 6.4,35 \mathrm{mM}$ EDTA $\mathrm{pH} \mathrm{8}$, and 2.6\% (w/v) Triton X-100) (Boom R., Sol C.J.A., Salimans M.M.M., Jansen C.L., Wertheim-van Dillen P.M.E., van der Noordaa J. 1990: J. Clin. Microbiol. 28: 495-503), $60 \mu \mathrm{l}$ of isoamyl alcohol and $0.5 \mathrm{~g}$ of $0.5 \mathrm{~mm}$ diameter zirconia/silica beads (Biospec Products, Inc., Bartlesville, Oklahoma) were added into $1.9 \mathrm{ml}$ Eppendorf tubes. The tubes were then shaken in a MiniBeadbeater (Biospec Products, Inc.) for $2 \mathrm{~min}$ at maximum speed, left at room temperature for $5 \mathrm{~min}$ and centrifuged at $12,000 \mathrm{~g}$ for $15 \mathrm{~s}$. The supernatant was transferred to another tube, to which $40 \mu \mathrm{l}$ of coarse activated silica suspension (Boom et al. 1990, op. cit.) were added. The suspension was then mixed in a Vortex mixer and allowed to stand at room temperature for $10 \mathrm{~min}$ and, after centrifugation (as above), the supernatant was discarded. The pellet was washed by centrifugation, twice with $200 \mu$ of L2 washing buffer $(10 \mathrm{M}$ guanidinium thiocyanate, $0.1 \mathrm{M}$ Trishydrochloride) (Boom et al. 1990, op. cit.), twice with $200 \mu 1$ of ice-cold $80 \%$ ethanol, and once with $200 \mu 1$ of acetone. The acetone was discarded and the pellet dried at $55^{\circ} \mathrm{C}$ for $5 \mathrm{~min}$; $100 \mu 1$ of water were added and, after vortexing briefly, the tube was incubated at $55^{\circ} \mathrm{C}$ for $5 \mathrm{~min}$. It was then centrifuged for $2 \mathrm{~min}$ at $12,000 \mathrm{~g}$ and the supernatant was transferred to another tube.

In a second phase, the nucleic acid sample was treated with polyvinyl pyrrolidone (PVP) to remove potential inhibitors of the PCR (Young C.C., Burghoff R.L., Keim L.G., MinakBernero V., Lute J.R., Hinton S.M. 1993: Appl. Environ. Microbiol. 59: 1972-1974). A $50 \mu 1$ aliquot of the extracted sample was added to $150 \mu \mathrm{l}$ of PVP-TE $(10 \%(\mathrm{w} / \mathrm{v})$ PVP (Sigma) in TE buffer), mixed and incubated at room temperature for $10 \mathrm{~min}$. The DNA was then selectively precipitated with isopropanol (Sambrook J., Maniatis T., Fritsch E.F. 1982: Molecular Cloning: A Laboratory Manual. Cold Spring Harbor Laboratory, Cold Spring Harbor, pp. E.10-E.15), 100 $\mu 1$ of $2.0 \mathrm{M}$ ammonium acetate and $600 \mu 1$ of isopropanol were added, mixed well and held at $-20^{\circ} \mathrm{C}$ for $30 \mathrm{~min}$. The tube was centrifuged $(12,000 \mathrm{~g}$ for $10 \mathrm{~min})$ and the supernatant fluid discarded carefully with a pipette. The precipitated DNA was dried with hot air and then reconstituted in $50 \mu 1$ of TE buffer and stored at $-20^{\circ} \mathrm{C}$ (Lawson A.J., Linton D., Stanley J., Owen R.J. 1997: J. Appl. Microbiol. 83: 375-380).

The primers selected for the PCR were GLC-1 (5'-AGG GCT CCG GCA TAA CTT TCC-3') and GLC-2 (5'-GTA TCT GTG ACC CGT CCG AG-3') (Abbaszadegan M., Huber 


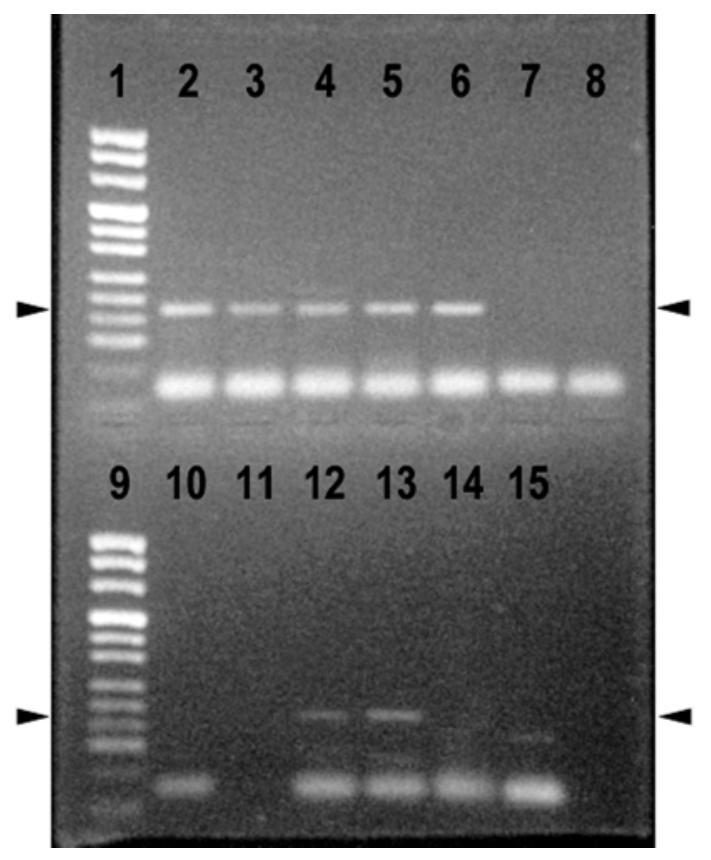

Fig. 1. Detection of the Giardia lamblia HSP gene in house flies by PCR and ethidium bromide-stained $1.8 \%$ agarose gel electrophoresis. Lanes 1 and 9: molecular weight marker $(\lambda$ Pst); lane 2: positive control; lane 8: negative control; lanes 36 and 12-13: positive samples; lanes 7, 10, 11, 14, 15: negative samples. Arrowheads: 163 base pairs.

M.S., Pepper I.L., Gerba C.P. 1993: In: Proc. Water Quality Technol. Conf., Am. Water Works Assoc., Miami, Flo., pp. $529-548$ ), which delimitate a 163 base pairs fragment of the
HSP of G. lamblia (Rochelle P.A., De León R., Stewart M.H., Wolfe R.L. 1997: Appl. Environ. Microbiol. 63: 106-114). Primers GLC-1 and GLC-2 correspond to a sequence recorded in GenBank (Benson D., Lipman D.J., Ostell J. 1993: Nucleic Acids Res. 21: 2963-2965.). PCR amplification was performed in $100 \mu \mathrm{l}$ total volumes, which included $10 \mu \mathrm{l}$ of extracted target DNA in $1 \times$ PCR buffer, $1.5 \mathrm{mM} \mathrm{MgCl}_{2}, 0.1$ $\mathrm{mM}$ of dNTPs, $15 \mathrm{pm}$ of each primer, and 1.25 units of Taq DNA Polymerase (Sigma). The tubes were subjected to 40 cycles of $94^{\circ} \mathrm{C}$ for $1 \mathrm{~min}, 55^{\circ} \mathrm{C}$ for $1 \mathrm{~min}$, and $72^{\circ} \mathrm{C}$ for $2 \mathrm{~min}$, followed by a final extension at $72^{\circ} \mathrm{C}$ for $10 \mathrm{~min}$. A $15 \mu \mathrm{l}$ aliquot of each PCR product was examined in a $1.8 \%$ agarose/ethidium bromide gel and photographed using ultraviolet transillumination and Polaroid Type 52 film.

Six hundred flies were processed. An amplification product of the expected size (163 bp) was detected in 13 of the 60 samples (22\%) (Fig. 1).

The role of arthropods (flies) in the indirect transmission of giardiasis has been long suspected but little investigated; we have found only three works related to the subject. Khan and Huq (1978, op. cit.) found Giardia cysts in $6.2 \%$ of 90 groups of 25 flies captured in Dacca, Bangladesh; this prevalence is lower than ours $(22 \%)$, but PCR is more sensitive than microscopic examination. In Poland, Kasprzak and Majewska (1981, op. cit.), examining wet mounts stained with $1 \%$ eosin, did not find any Giardia cysts in 308 flies of seven species, although they did find them in four out of 50 Periplaneta americana cockroaches (one nymph and three imagoes). Sterling et al. (1987, op. cit.) detected Giardia cysts by immunofluorescence microscopy in and on flies in an urban slum in Lima, Peru.

In conclusion, our data support the hypothesis that house flies can play a significant role in transmission of giardiasis. 